\title{
Sindrom McCune Albright Dengan Manifestasi Fraktur Berulang
}

\author{
Ruth Nadya,*Frida Soesanti \\ Departemen Ilmu Kesehatan Anak FKUI-RSCM Jakarta
}

\begin{abstract}
Abstrak
Sindrom McCune-Albright (SMA) merupakan kelainan genetik kompleks yang ditandai dengan trias displasia fibrosa poliostotik, café-au-lait, dan hiperfungsi endokrin. Sindrom ini termasuk penyakit langka dengan prevalens sebesar 1 per 100.000 hingga 1.000 .000 populasi. Mutasi somatik sporadik gen GNAS (Guanine Nucleotide binding protein Alpha Stimulating) pada kromosom 20q13, yang terjadi pada sindrom ini, mengakibatkan aktivasi $G$ protein $\alpha$-subunit (Gs $\alpha$ ) berkepanjangan yang meningkatkan aktivitas dan fungsi sel terkait. Manifestasi tersering yang ditemukan pada pasien adalah displasia fibrosa (pada 98\% kasus). Kasus adalah seorang anak lelaki, 10 tahun, dengan manifestasi fraktur berulang sejak usia 1 tahun dan deformitas tulang. Pemeriksaan bone survey menunjukkan gambaran ground glass dengan lesi litik-sklerotik pada hampir semua tulang yang sesuai dengan displasia fibrosa poliostotik. Pasien ditata laksana dengan pemberian sediaan fosfat, kalsium, serta vitamin D dalam bentuk aktif dan analog. Pemberian bisfosfonat bertujuan untuk mengurangi nyeri tulang dan risiko fraktur pada pasien. Pemantauan berkelanjutan diperlukan untuk mengevaluasi keterlibatan organ endokrin pada pasien dengan SMA.
\end{abstract}

Kata kunci: displasia fibrosa, fraktur, sindrom McCune Albright

\section{McCune Albright Syndrome with Recurrent Fracture}

Abstract

McCune-Albright syndrome (MAS) is a rare complex genetic disorder marked by the triad of polyostotic fibrous dysplasia, café-au-lait and endocrine hyperfunction, affecting 1 in 100.000 to 1.000 .000 population. The sporadic somatic mutation of Guanine Nucleotide Binding Protein Alpha Stimulating (GNAS) gene at chromosome 20q13 is the proposed cause of this syndrome, triggering the prolonged activation of $\mathrm{G}$ protein $\alpha$ subunit $(\mathrm{Gs} \alpha)$, which increases the activity and function of cells. The most common clinical manifestation is fibrous dysplasia, occurring in $98 \%$ cases. This case occurred in a 10 -year-old boy with recurrent fractures since the age of 1-year-old and skeletal deformities. The bone survey examination shows ground glass appearance with multiple sclerotic-lytic lesions on almost every bone, accordingly to the polyostotic fibrous dysplasia. The pasien has been treated with oral phosphate, calcium and vitamin D. Intravenous bisphosphonates was administered to relieve the associated bone pain and reduce the risk of recurring fractures. Longitudinal observation is necessary for a long term monitoring to evaluate the endocrinopathy associated with MAS.

Keywords: fibrous dysplasia, fractures, McCune-Albright syndrome,

*RN: Penulis Koresponden; E-mail: rnadya.p@gmail.com 


\section{Pendahuluan}

Sindrom McCune Albright (SMA) merupakan kelainan genetik kompleks yang ditandai dengan trias displasia fibrosa poliostotik, café-au-lait, dan hiperfungsi endokrin. ${ }^{1}$ Sindrom ini termasuk penyakit langka (rare disease) dengan prevalens sebesar 1 per 100.000 hingga 1 per 1.000.000 populasi. Pasien dengan SMA lebih banyak dilaporkan pada perempuan dibandingkan lelaki dan sering didiagnosis pada kisaran usia 4-5 tahun. ${ }^{2}$

Sindrom McCune Albright disebabkan oleh mutasi somatik sporadik gen) guanine nucleotide binding protein (GNAS1) pada lengan panjang kromosom 20 (20q13). ${ }^{2,3}$ Mutasi pada gen ini mengakibatkan aktivasi $G$ protein $\alpha$-subunit $(\mathrm{Gs} \alpha)$ berkepanjangan yang menstimulasi adenilat siklase dan meningkatkan produksi cyclic adenosine monophosphate (cAMP) intrasel sehingga terjadi peningkatan aktivitas dan fungsi sel. Manifestasi klinis bervariasi tergantung sel yang mengalami mutasi, misalnya mutasi pada osteoblas menyebabkan displasia fibrosa, pada sel melanosit menyebabkan pigmentasi café-au-lait, pada sel gonad menyebabkan pubertas prekoks. ${ }^{4,5}$ Pada banyak kasus, diagnosis SMA dapat ditegakkan setelah evaluasi gambaran tulang, endokrin, serta jaringan lunak dan kulit. Namun, pada beberapa kondisi seperti lesi tulang yang monostotik tanpa manifestasi kulit atau endokrin yang jelas diperlukan konfirmasi pemeriksaan histologi maupun molekuler. ${ }^{6}$ Manifestasi tersering yang ditemukan pada pasien adalah displasia fibrosa (pada 98\% kasus), bercak café-au-lait (pada 66\% kasus), serta kelainan pada gonad. Pada 69\% pasien, displasia fibrosa diketahui karena adanya keluhan fraktur yang dapat menyerupai kelainan tulang lainnya. ${ }^{7}$ Oleh karena itu, penting untuk dapat membedakan fraktur akibat SMA dengan fraktur yang lain sehingga dapat diberikan tata laksana secara komprehensif.

Sajian kasus ini bertujuan untuk mendiskusikan pendekatan klinis dalam penegakan diagnosis SMA dengan fraktur sebagai manifestasi utama. Informed consent telah dimintakan pada keluarga pasien dan disetujui.

\section{Laporan Kasus}

Seorang anak lelaki berusia 10 tahun, dirujuk ke RSCM pada tanggal 7 Oktober 2019 karena keluhan sulit berdiri dan berjalan sejak usia 1 tahun. Pasien lahir spontan, cukup bulan, berat badan lahir 3100 gram dan panjang badan lahir $50 \mathrm{~cm}$, tidak ada riwayat resusitasi aktif. Sejak lahir, pasien diketahui memiliki bercak coklat kehitaman di leher belakang dan bokong dengan bentuk tidak beraturan.

Usia 1 tahun pasien mulai berjalan, gerakan kaki saat itu tampak normal. Terdapat riwayat jatuh karena terpeleset dengan posisi jatuh tidak diketahui. Pasien tampak kesakitan saat posisi kaki diangkat. Pasien dibawa ke dukun patah tulang, dikatakan ada retak pada kaki kanan, dan mendapat terapi alternatif. Saat usia 3 tahun, pasien dapat berjalan kembali dengan bantuan alat bantu walau tampak pincang, tetapi tidak mampu berdiri atau berjalan dalam waktu lama. Pasien beberapa kali mengalami jatuh dan patah tulang. Pada usia 5 tahun, kaki kanan pasien mulai tampak bengkok sehingga makin sulit berjalan. Tangan kanan juga tampak bengkok setelah terjatuh dengan posisi tangan menahan badan. Pada usia 9 tahun kaki kiri tampak bengkok. Pasien sering mengeluh tulang-tulang terasa pegal hingga nyeri. Pasien sudah sempat dibawa berobat ke dokter ortopedi, namun karena proses diagnostik yang lama sehingga pasien dibawa untuk menjalani pengobatan alternatif.

Pasien merupakan anak ke-3 dari 3 bersaudara. Tidak ada anggota keluarga yang memiliki keluhan kelainan tulang, kelainan tiroid, tinggi badan yang sangat tinggi, atau menstruasi dini (Gambar 1). Ibu pasien menarke saat usia 12 tahun.

Saat ini pasien sudah kelas 4 SD dan memiliki prestasi yang baik di sekolah. Riwayat 
perkembangan kesan normal. Pasien dapat mengendarai sepeda roda tiga sebagai transportasi ke sekolah. Pasien memiliki nafsu makan yang baik, tetapi berat badan pasien sulit naik sejak usia sekitar 3 tahun.

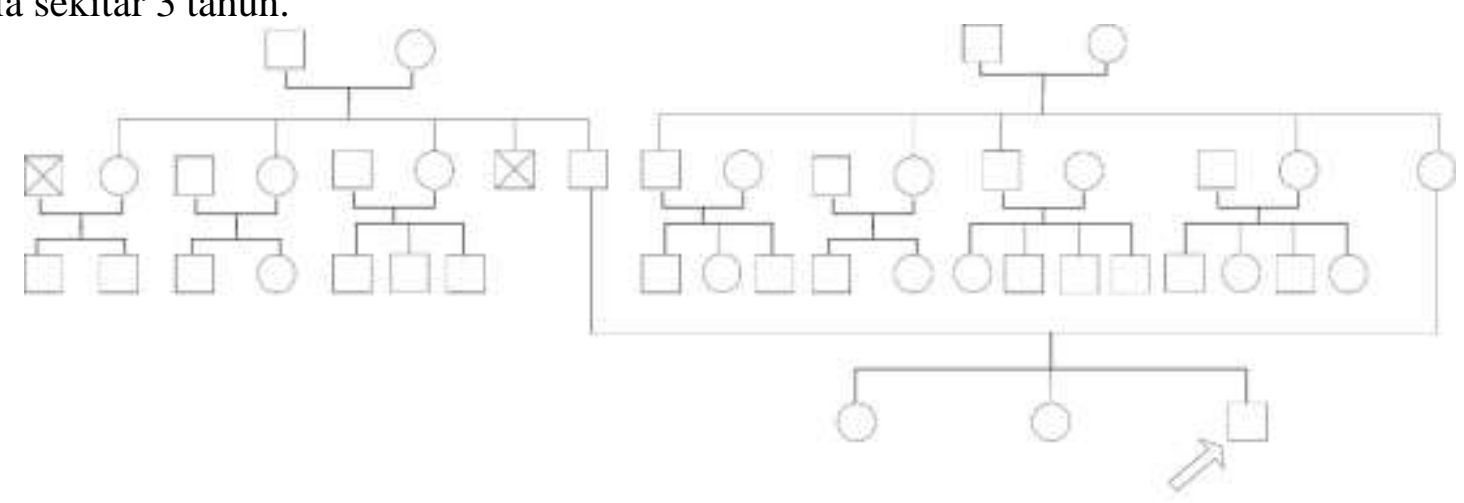

Keterangan:

Perempuan $\bigcirc$

Lelaki

Pasien

\section{Gambar 1. Genogram pasien}

Pada pemeriksaan fisik didapatkan pasien sadar dan tanda vital normal. Berat badan 18,4 $\mathrm{kg}\left(<\mathrm{P}_{3}\right.$, kurva $\left.\mathrm{CDC}\right)$ dan tinggi badan $94 \mathrm{~cm}\left(<\mathrm{P}_{3}\right.$, kurva $\left.\mathrm{CDC}\right)$. Lingkar lengan atas pasien $18,5 \mathrm{~cm}(88 \%)$ sesuai dengan gizi baik. Tinggi badan ayah $173 \mathrm{~cm}$, tinggi badan ibu $155 \mathrm{~cm}$, sehingga tinggi potensi genetik pasien adalah $162-179 \mathrm{~cm}$. Kepala normosefal, sklera tidak biru, tidak ada dentinogenesis imperfekta serta tidak ada sumbing atau kelainan lain di wajah. Pada pemeriksaan jantung, paru dan abdomen tidak ditemukan kelainan. Pada area punggung tampak skoliosis serta pada ekstremitas atas dan bawah terdapat "bowing" yang cukup berat (Gambar 2a). Pada pemeriksaan genitalia didapatkan panjang penis $5 \mathrm{~cm}$ dan volume kedua testis $3 \mathrm{ml}$. Ditemukan bercak café-au-lait menyerupai "coast of Maine" pada area leher belakang (Gambar 2b) dan bokong.

Saat itu pasien didiagnosis tersangka SMA dan dilakukan pemeriksaan bone survey dan bone mineral density (BMD) serta pemeriksaan laboratorium. Hasil pemeriksaan bone survey menunjukkan lesi litik multipel berbatas tidak jelas dengan ukuran bervariasi pada tulang kepala; pada toraks didapatkan ujung-ujung iga sebagian yang tampak melebar; gambaran bowing tampak pada femur dan tibia bilateral serta humerus dekstra; pada tulang panjang tampak multipel lesi lusen dengan tepi sklerotik. (Gambar 3 pada lampiran 1) Pemeriksaan BMD menunjukkan nilai z-score -4,5 dengan kesan low bone density for chronological age. Pada pemeriksaan laboratorium didapatkan kadar vitamin D25-OH yang rendah yaitu 12.3 $\mathrm{ng} / \mathrm{mL}$, kalsium ion 1,11 mg/dL dan kalsium total 9,3 mg/dL (normal), kadar fosfat rendah yaitu $2 \mathrm{mg} / \mathrm{dL}$, magnesium dalam batas normal (nilai $2,1 \mathrm{mg} / \mathrm{dL}$ ), alkali fosfatase (ALP) meningkat (nilai $2950 \mathrm{U} / \mathrm{L}$ ). Pemeriksaan ultrasonografi (USG) testis menunjukkan testis kanan normal, sedangkan pada testis kiri tampak kalsifikasi. Berdasarkan data klinik tersebut, pasien didiagnosis SMA dengan hipofosfatemia dan defisiensi vitamin D.

a)

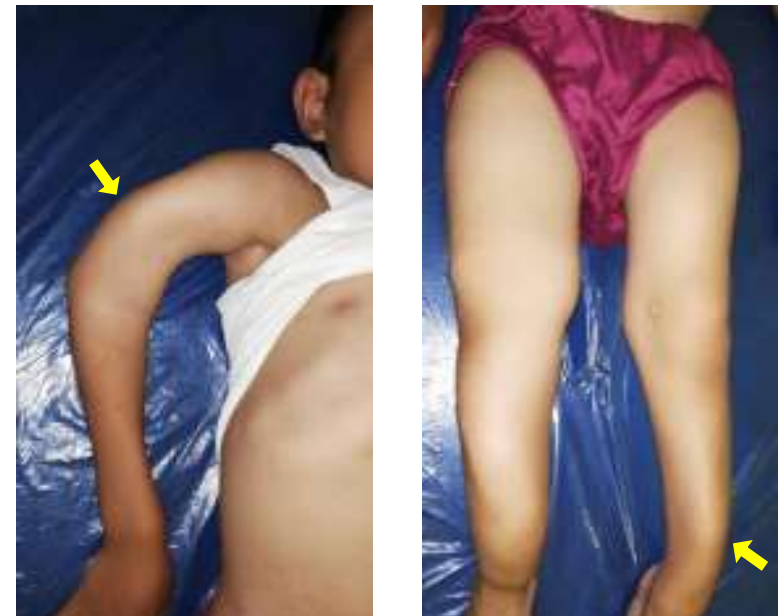

b)

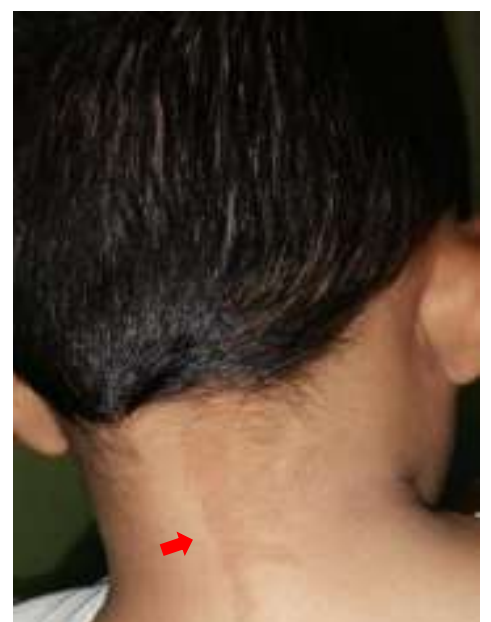


Gambar 2. a) Bowing pada pasien, b) Lesi café-au-lait pada pasien

Pemeriksaan genetil tidak dilakukan karena masalah biaya. Pasien diterapi dengan suplementasi vitamin D 1x2000 IU, kalsitriol 1x0,25 mcg, kalsium 1x500 mg, fleet fosfosoda dengan dosis $1 \mathrm{~mL}$ pagi hari, $0,5 \mathrm{ml}$ siang hari, dan $0,5 \mathrm{ml}$ malam hari. Setelah mendapatkan terapi tersebut selama 3 bulan pasien dapat berdiri dengan durasi yang lebih lama. Terhadap pasien dilakukan evaluasi kadar kalsium, fosfat, dan ALP untuk melihat respon terapi dan pengaturan dosis obat. Pasien mendapat bifosfonat (asam zoledronat) dengan dosis awal $0,025 \mathrm{mg} / \mathrm{kgBB}$ dilanjutkan dengan dosis $0,05 \mathrm{mg} / \mathrm{kgBB}$ setiap 6 bulan serta dilakukan fisioterapi oleh departemen rehabilitasi medik .

\section{Diskusi}

Seorang anak lelaki usia 10 tahun dengan SMA, datang karena keluhan kesulitan berdiri akibat riwayat fraktur berulang. Fraktur pada anak lebih sering didapatkan pada anak lelaki dibanding perempuan dengan rasio $3: 1 .^{8,9}$ Rentang usia tersering terjadinya fraktur pada anak lelaki adalah 12-14 tahun sedangkan pada anak perempuan usia 9-11 tahun. Hal ini disebabkan perbedaan penambahan panjang tulang dan proses mineralisasi tulang sehingga terdapat penipisan korteks tulang secara relatif. ${ }^{9}$ Kasus ini adalah pasien laki-laki mengalami fraktur berulang pada dekade pertama kehidupannya.

Lokasi tersering fraktur adalah ekstremitas atas (76,7\%), dan tulang tersering yang mengalami fraktur adalah radius $(32,1 \%)$ pada ekstremitas atas dan femur $(31,7 \%)$ pada ekstremitas bawah, tergantung pada mekanisme cidera dan usia anak. ${ }^{8,9}$ Terjadinya fraktur dipengaruhi oleh faktor ekstrinsik seperti derajat dan mekanisme trauma, dan faktor intrinsik seperti kelenturan, densitas dan kekuatan tulang. Kekuatan tulang sangat dipengaruhi oleh proses modelling (ukuran dan bentuk) serta kepadatan mineral dan komposisi tulang. Sekitar $80 \%$ massa, pembentukan dan kekuatan tulang ditentukan oleh genetik, sedangkan sisanya dipengaruhi oleh massa otot (15\%) dan faktor lain (5\%), seperti hormon pubertas, asupan kalsium, serta kadar vitamin D. ${ }^{10}$ Pasien mengalami riwayat fraktur berulang dengan atau tanpa riwayat trauma sehingga dapat dipikirkan adanya gangguan kepadatan tulang atau suatu fraktur patologis. Adanya fraktur patologis disertai deformitas tulang dan bercak café-au-lait menimbulkan kecurigaan terhadap kemungkinan kasus SMA.

Etiologi fraktur berulang, sebagian besar disebabkan kelainan genetik yang memengaruhi aktivitas osteoblas, osteoklas, atau pun sintesis kolagen pada tulang, seperti osteogenesis imperfekta dan dIsplasia fibrosa. ${ }^{10}$ Lesi pada tulang dapat terlihat pada satu tulang 
(monostotik, pada 70-85\% pasien) atau beberapa tulang (poliostotik, pada $15-30 \%$ pasien) dan dapat mengakibatkan deformitas, fraktur, gangguan fungsi, atau nyeri pada tulang. ${ }^{10,11}$ Displasia fibrosa dapat terjadi secara tersendiri maupun disertai dengan manifestasi ekstraskeletal, seperti bercak café-au-lait dan kelainan endokrin. Kombinasi dua atau lebih dari kondisi displasia fibrosa, bercak café-au-lait, dan hiperfungsi endokrinopati disebut sebagai SMA., ${ }^{5,6}$ Diagnosis SMA dapat ditemui pada 5\% pasien dengan displasia fibrosa dan $50 \%$ dari kasus displasia fibrosa poliostotik. ${ }^{11,12}$

Gangguan tulang berupa displasia fibrosa pada SMA dapat mengenai satu atau lebih tulang pada area tersering mengenai dasar tengkorak dan femur proksimal. Selain fraktur, displasia fibrosa dapat menyebabkan nyeri hingga deformitas berupa bowing, diskrepansi panjang kaki, asimetri wajah, benjolan pada tulang iga, atau skoliosis. Sebagian besar deformitas ini terjadi pada tulang penyangga beban. Pada regio kraniofasial, deformitas tulang dapat menimbulkan keluhan gangguan penglihatan, pendengaran, kongesti nasal, hiposmia, atau maloklusi. Kelainan pada berbagai area tulang ini biasanya mulai terjadi pada awal masa kanak-kanak hingga usia sekitar 15 tahun, dengan insidens fraktur tertinggi terjadi pada usia 6-10 tahun dan menurun setelahnya. ${ }^{4,5}$

Pasien dengan displasia fibrosa dapat mengalami gangguan tulang pada regio apendikular, kraniofasial, maupun aksial. Manifestasi displasia fibrosa mulai tampak pada dekade pertama kehidupan, 90\% lesi kraniofasial muncul pada usia 3,4 tahun, 90\% lesi regio apendikular tampak pada usia 13,7 tahun, dan $90 \%$ lesi aksial timbul pada usia 15,5 tahun. ${ }^{5,13}$ Gejala yang biasa timbul pada area apendikular adalah nyeri, kelemahan, hingga fraktur patologis pada tulang, sedangkan pada kraniofasial pasien biasanya mengeluhkan adanya benjolan yang tidak nyeri atau asimetri pada wajah. ${ }^{11}$ Kondisi poliostotik displasia fibrosa akan meningkatkan risiko terjadinya fraktur. Selain itu, gangguan metabolik atau hormonal yang menyertai kondisi displasia juga dapat memengaruhi terjadinya fraktur. Fraktur pada area tulang yang mengalami gangguan dapat pulih kembali, tetapi area tersebut rentan untuk mengalami fraktur kembali. Pada pasien ini terdapat keluhan tungkai atas dan bawah yang tampak bengkok serta timbul benjolan. Pada area punggung tampak skoliosis serta pada ekstremitas atas dan bawah terdapat "bowing" yang cukup berat.

Bercak café-au-lait dapat timbul sebagai tanda lahir pada 2,7\% kelahiran atau dapat timbul saat usia balita ( $25 \%$ kasus). Bercak yang timbul dengan ukuran $\geq 5 \mathrm{~mm}$, multipel, disertai kelainan wajah atau kulit perlu dievaluasi adanya keterkaitan dengan penyakit lain, seperti neurofibromatosis, SMA, anemia Fanconi, tuberosklerosis, atau ataksia telangiektasia. ${ }^{14}$ Pada pasien ini terdapat bercak café-au-lait di regio leher belakang sisi kanan pasien sejak lahir juga menjadi salah satu manifestasi dari trias SMA. Lesi kulit ini berupa makula hiperpigmentasi, berbatas tegas dengan bentuk tidak beraturan, serta tidak terdapat pertumbuhan rambut di atasnya.

Pada SMA, bercak café-au-lait tampak pada 53-95\% kasus dengan ciri khas makula terdapat pada satu sisi, tidak melewati garis tengah tubuh, dan umumnya terdistribusi pada area dada, leher, serta lipat paha. Tepi bercak berbentuk tidak reguler menyerupai coast of Maine, sedangkan tepi yang reguler (coast of California) merupakan ciri khas lesi neurofibromatosis. ${ }^{5,14}$ Pada pasien ini terdapat kelainan di area punggung tampak skoliosis serta pada ekstremitas atas dan bawah terdapat "bowing" yang cukup berat. Pada pemeriksaan genitalia didapatkan panjang penis $5 \mathrm{~cm}$ dan volume kedua testis $3 \mathrm{ml}$. Ditemukan bercak café-au-lait menyerupai "coast of Maine" pada area leher belakang dan bokong. Semua manifestasi klinis pada pasien ini merupakan manifestasi kinis SMA.

Pemeriksaan radiologi pada displasia fibrosa didapatkan gambaran ground-glass pada matriks tulang dengan penipisan lapisan korteks; lesi radiolusen (kistik), lesi sklerotik, atau kombinasi keduanya. Pada regio vertebra dapat ditemukan gambaran skoliosis, sedangkan pada area ekstremitas dapat dijumpai gambaran deformitas bowing, looser zones (milkman 
lines atau pseudofraktur), coxa vara ("shepherd's crook") pada femur proksimal, atau penutupan lempeng pertumbuhan dini pada kondisi yang disertai pubertas prekoks. ${ }^{6}$ Pemeriksaan bone scan merupakan modalitas yang sensitif untuk mendeteksi displasia fibrosa, meskipun terkadang MRI dapat digunakan untuk membedakan lesi displasia fibrosa dengan kista.

Pada pasien ini, hasil bone survey menunjukkan gambaran ground glass appearance serta lesi litik sklerotik pada tulang panjang, kepala, serta ekstremitas menunjukkan adanya gangguan pembentukan matriks tulang yang normal. Fraktur berulang pada tulang penyangga beban tubuh dengan penyembuhan yang tidak sempurna dapat menyebabkan terbentuknya deformitas seperti bowing pada ekstremitas atas dan bawah, atau Shepherd Crook pada area leher femur, seperti yang didapatkan pada pasien. Pemeriksaan BMD dengan hasil low bone density menunjukkan risiko pasien akan terjadinya fraktur berulang.

Pada SMA, kelainan akibat stimulasi protein Gs $\alpha$ terjadi pada beberapa lokasi. Lokasi yang mengalami gangguan tampak pada manifestasi klinis yang timbul, seperti bercak caféau-lait, peningkatan fungsi gonad terkait gonadotropin, hipertiroid, kelebihan hormon pertumbuhan, atau hiperkortisol pada neonatus. ${ }^{5,6}$ Keterlibatan testis pada anak lelaki dengan SMA mencapai hingga $85 \%$ kasus dan $15 \%$ di antaranya mengalami produksi testoteron berlebih sehingga mengalami androgenisasi. ${ }^{4}$ Oleh karena manifestasi yang seringkali tersembunyi, evaluasi laboratorium pada hormon pertumbuhan, hormon tiroid, LH-FSH dan testosteron, serta USG tiroid diperlukan untuk memastikan adanya gangguan fungsi pada organ. ${ }^{7}$ Pasien tidak menunjukkan gejala klinis hipertiroid, dan pemeriksaan status pubertas menunjukkan pasien belum mengalami pubertas. Pada pemeriksaan USG testis didapatkan gambaran kalsifikasi pada testis kiri. Hal ini disebabkan mutasi Gs $\alpha$ yang mengakibatkan hiperfungsi gonad terbatas pada sel sertoli sehingga dapat terjadi mikrolitiasis atau kalsifikasi fokal pada testis maupun pembesaran testis unilateral atau bilateral tanpa tanda pubertas prekoks. $^{7}$

Terapi pada SMA diberikan sesuai dengan gejala spesifik yang timbul pada setiap pasien. Hingga saat ini belum ada terapi medikamentosa yang efektif mencegah progresivitas displasia fibrosa, tetapi bisfosfonat dipertimbangkan menjadi salah satu terapi pilihan. Pada displasia fibrosa, terjadi peningkatan kadar osteoklas sehingga berkontribusi terhadap terjadinya fraktur. Bifosfonat berperan menghambat resorpsi tulang melalui stimulasi apoptosis osteoklas sehingga menurunkan bone turnover. ${ }^{4}$ Terapi bisfosfonat diberikan pada pasien untuk menurunkan bone turnover sehingga membantu memperbaiki keluhan nyeri dan kejadian fraktur. ${ }^{15}$

Kadar fosfat yang rendah pada pasien disebabkan produksi fibroblast growth factor 23 (FGF23) yang berlebih oleh jaringan displasia fibrosa. Semakin tinggi kadar FGF23, semakin tinggi keluaran fosfat melalui ginjal (urin), semakin rendah kadar fosfat serum. Dampak hipofosfatemia adalah fraktur yang terjadi pada usia dini, fraktur yang berulang, dan nyeri pada tulang. Oleh karena itu, kondisi hiposfosfatemia dapat memperberat kondisi displasia fibrosa yang dimiliki akibat gangguan proses mineralisasi tulang. ${ }^{16}$ Pemberian fosfat diperlukan untuk menurunkan risiko fraktur dan nyeri. Terapi diawali dengan pemberian metabolit aktif atau analog vitamin D, berupa kalsitriol atau alfakalsidol, dengan dosis 15-60 $\mathrm{ng} / \mathrm{kg} / \mathrm{hari}$. Fosfat kemudian diberikan secara per oral dengan dosis $15-60 \mathrm{mg} / \mathrm{kg} / \mathrm{hari}$, dosis dititrasi untuk mempertahankan kadar fosfat pada batas bawah rentang normal kadar fosfat serum. Efek samping terapi fosfat berupa gangguan gastrointestinal. Perlu dilakukan pemantauan pada terapi jangka panjang vitamin D aktif dan fosfat karena dapat menyebabkan hiperparatiroid serta nefrokalsinosis. ${ }^{2,6}$ Pasien sudah mendapat terapi yang tepat dengan pemberian fosfat per oral dengan dosis minimal yang dinaikkan bertahap dengan memantau kadar fosfat dalam darah. Vitamin D dan kalsium diberikan pada pasien sebagai terapi defisiensi vitamin D dan memperbaiki mineralisasi tulang. 
Skoliosis pada pasien juga perlu dievaluasi berkala. Penggunaan fiksasi melalui pembedahan dapat dipertimbangkan bila sudut Cobb lebih besar dari 30 derajat, tergantung dari progresivitas serta lokasinya. ${ }^{6}$ Adanya keterlibatan testis pada pasien perlu dinilai lebih lanjut. Bila didapatkan adanya peningkatan hormon testosteron atau percepatan usia tulang, dapat diberikan terapi testosterone receptor blocker dan aromatase inhibitor. ${ }^{4,6}$

Prognosis pasien dengan SMA bervariasi tergantung pada manifestasi klinis yang timbul dan derajat beratnya. Secara keseluruhan angka harapan hidup pasien dengan SMA baik, akan tetapi pada kondisi SMA dengan keterlibatan organ vital, seperti jantung, dapat menimbulkan kematian pada usia dini. Prognosis quo ad vitam pasien adalah bonam karena berdasarkan gejala yang timbul tidak tampak mengenai area yang vital, tetapi perlu dilakukan pemeriksaan lanjutan terhadap fungsi jantung serta MRI kepala untuk melihat keterlibatan hipofisis. Quo ad functionam pasien adalah dubia ad bonam karena deformitas, terutama pada ekstremitas, mengganggu mobilisasi pasien. Pasca pemberian terapi pasien mulai dapat berdiri dengan durasi yang lebih lama. Tidak ada gangguan penglihatan dan pendengaran yang ditemukan pada pasien. Quo ad sanactionam pada pasien adalah dubia ad malam karena displasia fibrosa yang biasanya progresif. Terapi bisfosfonat (asam zoledronat) diharapkan dapat mencegah progresivitas displasia fibrosa serta mengurangi frekuensi fraktur dan nyeri pada tulang.

\section{Kesimpulan}

Sindrom McCune Albright (SMA) merupakan kelainan genetik kompleks yang ditandai dengan trias displasia fibrosa poliostotik, café-au-lait, dan hiperfungsi endokrin. Diagnosis SMA dapat ditegakkan setelah evaluasi gambaran tulang, endokrin, serta jaringan lunak dan kulit. Tata laksana komprehensif meliputi berbagai bidang seperti pediatrik, ortopedik, dermatologik, rehabilitasi medik, serta dukungan psikososial. Prognosis pasien dengan SMA bervariasi tergantung pada manifestasi klinis yang timbul dan derajat beratnya.

\section{Daftar Pustaka}

1. Hou JW. McCune-Albright Syndrome: Diagnosis and clinical course in eleven patients. Pediatr Neonatol. 2018;59:418-20.

2. National Organization for Rare Disease. McCune Albright Syndrome. 2017 [Diakses tanggal 18 Mar 2020]. Tersedia di: https://rarediseases.org/rare-diseases/mccune-albright-syndrome.

3. Cho EK, Kim J, Yang A, Ki CS, Lee JE, Cho SY, et al. Clinical and endocrine characteristics and genetic analysis of Korean children with McCune-Albright Syndrome: a retrospective cohort study. Orphanet J. Rare Dis. 2016;11:113-20.

4. Spencer T, Pan KS, Collins MT, Boyce AM. The clinical spectrum of McCune-Albright Syndrome and its management. Horm Res Paediatr. 2019;1:1-10.

5. Boyce AM, Collins MT. Fibrous dysplasia/McCune-Albright Syndrome: a rare, mosaic disease of Gas activation. Endocr Rev. 2019;1:1-63.

6. Javaid MK, Boyce A, Dijkstra NA, Ong J, Defabianis P, Offiah A, et al. Best practice management guidelines for fibrous dysplasia/McCune-Albright Syndrome: a consensus statement from the FD/MAS international consortium. Orphanet J Rare Dis. 2019;14:139-55.

7. Collins MT, Singer FR, Eugster E. McCune-Albright Syndrome and the extraskeletal manifestations of fibrous dysplasia. Orphanet J Rare Dis. 2012;7:1-14.

8. Aygün Ü. The feature assessment of the bone fractures in 1020 children and review of the literature. North Clin Istanb. 2020;7:1-7.

9. Valerio G, Gallè F, Mancusi C, Caterina, Onofrio VD, Colapietro M, et al. Pattern of fractures across pediatric age groups: analysis of individual and lifestyle factors. BMC Public Health. 2010;10:656-64.

10. Korula S, Titmuss AT, Biggin A, Munns CF. A practical approach to children with recurrent fractures. Endocr Dev. 2015;28:210-25.

11. Utriainen P, Valta H, Björnsdottir S, Mäkitie O, Horemuzova E. Polyostotic fibrous dysplasia with and without McCune-Albright Syndrome: clinical features in a Nordic pediatric cohort. Front Endocrinol. 2018;9:1-8. 
12. Özşen M, Yalçinkaya Ü, Bilgen MS, Yazici Z. Fibrous dysplasia: clinicopathologic presentation of 36 cases. Turk Patoloji Derg. 2018;34:234-41.

13. Robinson C, Collins MT, Boyce AM. Fibrous dysplasia/McCune-Albright Syndrome: clinical and translational perspectives. Curr Osteoporos Rep. 2016;14:178-86.

14. Shah KN. The diagnostic and clinical significance of café-au-lait macules. Pediatr Clin North Am. 2010;57:1131-53.

15. Wang Y, Wang O, Jiang Y, Li M, Xia W, Meng X, dkk. Efficacy and safety of bisphosphonate therapy in McCune-Albright syndrome-related polyostotic fibrous dysplasia: a single-center experience. Endocr Pract. 2019;25:23-30.

16. Majoor BC, Dijkstra NM, Fiocco M, Sande MA, Dijkstra S, Hamdy NA. Outcome of long-term bisphosphonate therapy in MAS and PFD. J Bone Miner Res. 2017;32:264-76. 
Lampiran 1

Pemeriksaan bone survey pasien
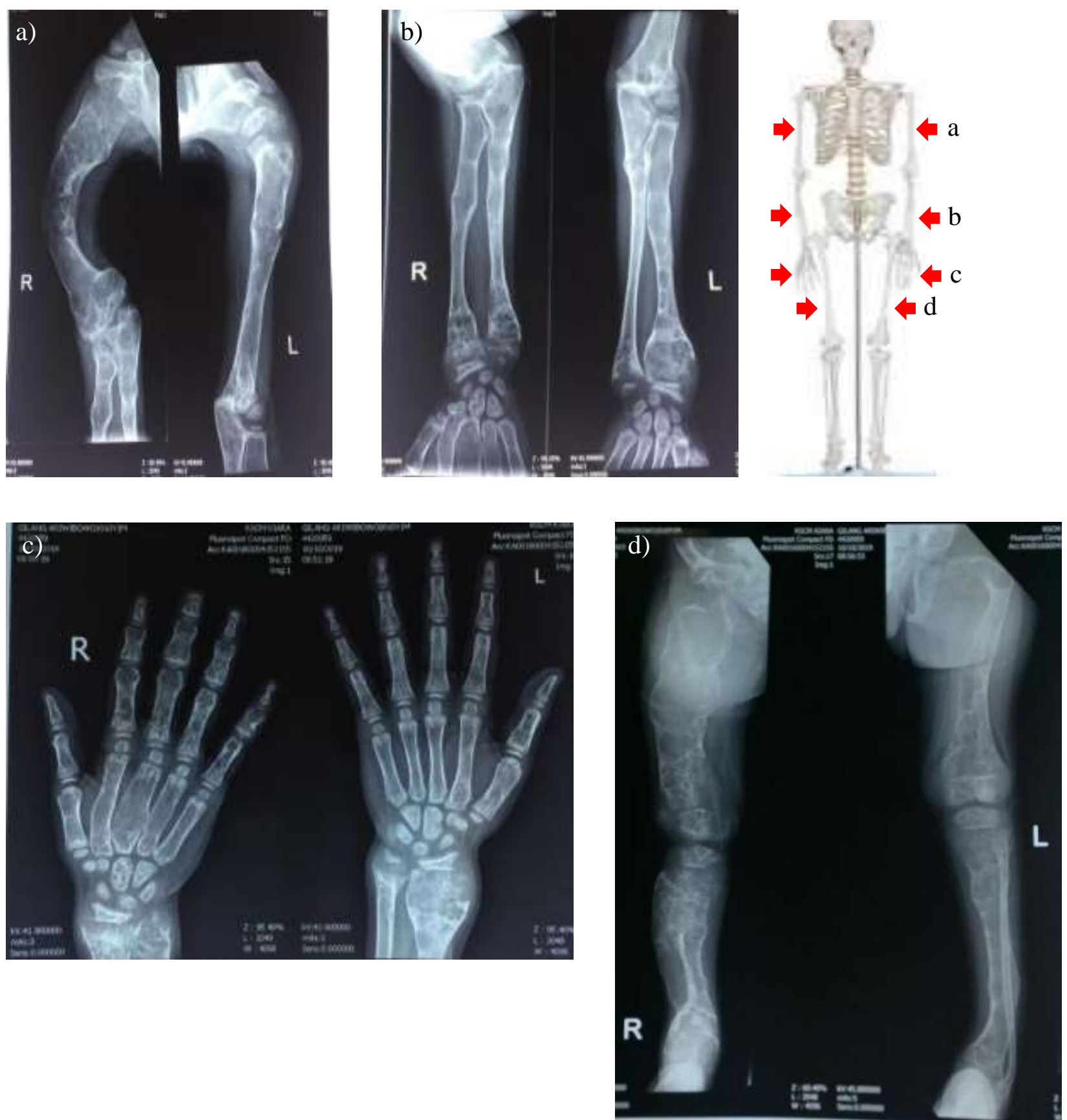

Gambar 3. Hasil bone survey pasien 